Comparative \& Physiological Psychology, $1966,62,437-440$.

RESSLER, R. H. Parental handling in two strains of mice reared by foster parents. Science, $1962,137,129-130$

RESSLER, R. H. Genotyped-correlated parental influence in two strains of mice. Journal of Comparative \& Physiological Psychology, $1963,56,882-886$.

SAYLER, A., \& SALMON, M. Communal nursing in mice: Influence of multiple mothers on the growth of the young. Science, 1969, $164,1309-1310$.

TENCZAR, P., \& BADER, R. S. Maternal effect in dental traits of the house mouse. Science $1966,152,1398-1400$.

\title{
Sucrose preference in rats following amygdaloid lesions
}

ERNEST D. KEMBLE, I JACK T. TAPP, and ROGER S. ZIMMERMAN, ${ }^{2}$ Vanderbilt University, Nashville, Tenn. 37203

Preference for seven increasingly concentrated sucrose solutions was examined in amygdala-lesioned and control rats. Although the amygdaloid Ss tended to show less preference for .01 and $.03 \mathrm{M}$ sucrose, their performance was well within normal limits for the remaining concentrations. It is suggested that amygdaloid hyporeactivity to positive taste stimuli may be brief in duration.

A number of experiments have implicated the amygdaloid complex in motivational processes. Grossman (1963, 1964) found that electrical or chemical stimulation and ablation within the amygdaloid complex of rats reliably altered food and water intake. Schwartzbaum $(1960,1961)$ has also shown that operant response rates of monkeys are insensitive to changes in magnitude of reward and prolonged food deprivation following extensive amygdaloid lesions. Recently Kemble \& Schwartzbaum (1969) found that short-term licking rates for $2 \%, 8 \%$, and $32 \%$ sucrose solutions were reduced, while daily quinine solution consumption was temporarily increased, in rats following amygdaloid lesions. These results suggest the possibility that the amygdaloid complex may function, in part, to modulate the incentive properties of taste
WERBOFF, J., HAGGETT, B. N., \& ANDERSON, A. Swimming performance of mice: Time to submersion as a function of water temperature. Physiology \& Behavior, $1967,2,39-43$

\section{NOTES}

1. This research was supported in part by USPHS Research Grant No. HD-04158 from the National Institute of Child Health and Human Development. The technical assistance of $\mathrm{J}$. Jeffery Laverty and William Gensel is gratefully acknowledged.

2. Now at George Peabody College, Nashville, Tenn. 37203.
$(\mathrm{N}=10)$ were produced by passing $2.0-\mathrm{mA}$ current from a Grass radio frequency lesion maker through the uninsulated tip of a 24-ga hypodermic needle for $20 \mathrm{sec}$. Four Ss received control operations, and the remaining $(\mathrm{N}=3)$ Ss served as normal control Ss. There were no reliable differences between the two control groups, and their data were pooled for further analyses.

All tests were conducted in S's ( $7 \times 14 \times 7$ in.) home cage, which had been adapted to accept the drinking spouts of two 100-ml drinking cylinders which were mounted on the front of the cage approximately 4 in. apart. Seven sucrose solutions were used as test substances, with concentration increasing in equal log-molar steps $(.001, .003, .01, .03, .1, .3,1.0 \mathrm{M})$. Ss were tested for 2 days at each sucrose concentration, with the position of the sucrose cylinder reversed each day. The remaining graduated cylinder always contained tap water.

At the conclusion of the experiment, 40-micron coronal sections were prepared and stained with cresyl violet through the area of the amygdaloid lesions.

RESULTS AND DISCUSSION

stimuli. The present experiment further explores this possibility, using a wider range of sucrose concentrations and the more traditional two-bottle preference test.

\section{SUBJECTS}

The Ss were 17 male albino Sprague-Dawley rats, 140-160 days old at the beginning of the experiment. These Ss previously served in an experiment to determine the effects of amygdaloid lesions on general activity levels.

All operations were carried out under clean conditions with sodium pentobarbital anesthesia $(50 \mathrm{mg} / \mathrm{kg})$. Amygdaloid lesions
The amygdaloid lesions in this experiment consistently damaged the cortical, basal, and central amygdaloid nuclei, while the medial $(\mathrm{N}=8)$ and lateral $(\mathrm{N}=7)$ amygdaloid nuclei frequently escaped damage. Occasional damage to the optic tracts $(\mathrm{N}=2)$ and caudate-putamen $(\mathrm{N}=3)$ was also noted but produced no detectable changes in performance.

Initial comparisons failed to suggest any reliable differences between the amygdaloid and control groups in total fluid consumption or body weight. Moreover, both groups showed a reliable increase in fluid consumption with

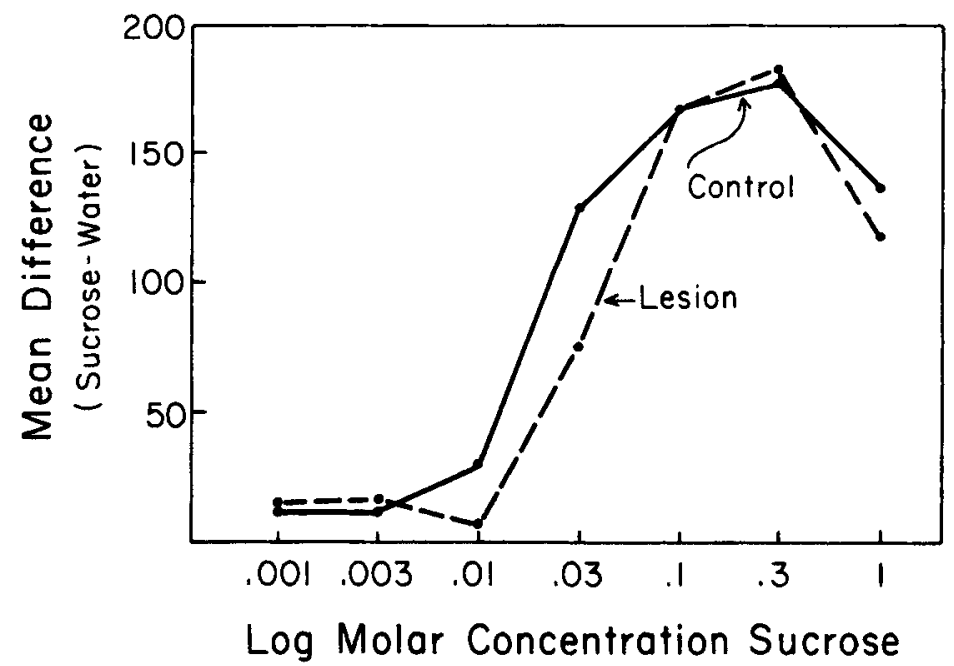

Figure 1. 
increases in sucrose concentration $(F=101, \mathrm{df}=6 / 90, \mathrm{p}<.001)$ and drank more sucrose solution than water $(\mathrm{F}=1,206, \mathrm{df}=1 / 15, \mathrm{p}<.001)$. Mean sucrose-water differences during preference testing are presented in Fig. 1. Although there were no reliable group differences $(\mathrm{F}<1.0)$, analysis of variance indicated a significant Les:on by Sucrose Concentration interaction $(F=2.74$, $\mathrm{df}=6 / 90, \mathrm{p}<.05)$. It may be seen in Fig. 1 that this resulted primarily from a decrease in sucrose preference by the amygdaloid $\mathrm{Ss}$ at $.03 \mathrm{M}$ sucrose $(t=1.91$, $\mathrm{df}=16, \mathrm{p}<.10$ ).

Although the sucrose preference of the amygdaloid $S s$ in this experiment tended to be somewhat depressed at lower concentrations, their performance for the remaining solutions was within normal limits. These results suggest that amygdaloid hyporeactivity to taste stimuli may be confined to relatively brief exposures and is obscured by daily consumption measures. Thus Kemble \& Schwartzbaum (1969) found that amygdaloid Ss consumed less $32 \%$ sucrose than did control Ss during the first $31 / 2 \mathrm{~min}$ of testing but that the groups were indistinguishable when consumption was compared for the entire 14-min session. Similarly, 24-h single-bottle saccharin solution consumption failed to discriminate between amygdaloid and control Ss. A more extensive series of experiments is now being conducted.

\section{REFERENCES}

GROSSMAN, S. P., \& GROSSMAN, L. Food and water intake following lesions or electrical stimulation of the amygdala. American Journat of Physiology, 1963, 205, 761-765.

GROSSMAN, S. P. Behavioral effects of chemical stimulation of the ventral amygdala. Journal of Comparative \& Physiological Psychology, $1964,57,29-36$

KEMBLE, E. D., \& SCHWARTZBAUM, J. S. Reactivity to taste properties of solutions following amygdaloid lesions. Physiology \& Behavior, 1969, 4, 981-985.

SCHWARTZBAUM, J. S. Changes in reinforcing properties of stimuli following ablation of the amygdaloid complex in monkeys. Journal of Comparative \& Physiological Psychology, 1960, 53, 388-395.

SCHWARTZBAUM, J. S. Some characteristics of "amygdaloid hyperphagia" in monkeys. American Journal of Psychology, 1961, 74, 252-259.

NOTES

1. Now at the University of Rochester. 2. Now at Bishop's University. 